\title{
Evaluation of Market Relations in Soft Milling Wheat Agri-food Chain
}

\author{
L. Rumánková \\ Faculty of Economics and Management, Czech University of Life Sciences Prague, Czech Republic
}

\begin{abstract}
This paper deals with the assessment of price transmission in partial chains of soft milling wheat on example of the Czech Republic. The price transmission examination is accompanied by an international comparison of analyzed topic. The analysis is carried out for the chain of smooth flour, white baked goods and consumer bread. In all cases, the relation of the farm-gate price - wholesale price - consumer price is examined. The aim of the article is to address the question of whether all of the partial product chains of soft milling wheat can be considered identical in terms of the formation of the price and its transmission to other levels. The analysis itself is based upon variables in the form of time series containing monthly data for the period of January 1999 - October 2011, the time series contain 154 observations. Subsequently, the possibility of the results generalization was verified based on the results of the price transmission in period of January 2012 - December 2015. Price transmission is modeled with the utilization of the Vector Error Correction Model and co-integration analysis. The research showed certain congruent features of the analyzed chains, which can be further generalized. However, significant differences were also established, which constitute the uniqueness of each chain. One-way relations were established on some market levels, while mutual relations were established on others. Overall, the relations in the analyzed agri-food chains can be considered long-term, inelastic and demand-driven. Price transmissions in the chains do occur, individual changes in partial prices are followed by the relevant reaction.
\end{abstract}

\section{Keywords}

Agri-food chain, farm-gate price, wholesale price, consumer price, soft milling wheat, price transmission, co-integration analysis, VECM.

Rumánková, L. (2016) "Evaluation of Market Relations in Soft Milling Wheat Agri-food Chain", AGRIS on-line Papers in Economics and Informatics, Vol. 8, No. 4, pp. 133 - 141. ISSN 1804-1930. DOI 10.7160/aol.2016.080412.

\section{Introduction}

The economic crisis has influenced the efficiency as well as competitiveness of all subjects in national economies all around the world. The prices play the key role in relationships between farmers, retail and consumers. The issue of the agricultural and foodstuffs market together with the issue of the purchasing power of consumers, primarily in relation to essential goods and their willingness, is among the principal topics of recent years. In connection with the accession of the Czech Republic to the European Union as well as with the economic crisis, the position of farmers in individual sectors has changed as compared to their previous situation. Producers, as well as processors and consumers, are forced to react to such changes.

Putičová, Mezera (2011) analyzed competitiveness of the Czech food industry. Among other things, their study shows that sector competitiveness is not critical. Further, the authors emphasize the fact that food producers currently face the basic problems in the output sphere mainly in the domestic market. Kita et al (2012) states that relations between food producers and retailers are connected with the economic situation of farmers characterized by the share of agriculture in GDP and the situation of retailers in negotiating with their suppliers. In relation to the consumers' behavior, Šrédl, Soukup (2011) state that in connection to the current economic crisis, there is increased interest in the private assortment brands due to the pricequality ratio as a good alternative to the branded products. Syrovátka (2006) states that a significant role in the decision-making of consumers is held by their income level. Demand relationships can thus be measured with the utilization of income elasticity of consumer demand. Luňáček and Feldbabel (2011) further emphasize 
the importance of price elasticity of demand, which shows the "willingness" of consumers to purchase individual goods and on the basis of which vendors can make decisions in setting the price of food products. Kim (2012) adds that end consumers are, in relation to the other segments of the chain, disadvantaged because of asymmetrical information. It can be assumed that the most advantageous position within agri-food chains is had by merchants, primarily large retail chains, upon whom both agricultural producers as well as consumers are dependent. However, the situation and market relations in individual chains differ, and thus a detailed analysis is desirable in this regard.

The agri-food chain is generally made up of interconnected segments within the production chain. The agri-food chain generally covers agricultural producers including suppliers of inputs into the agricultural chain, processors of agricultural raw materials, merchants as well as end consumers. As stated by Pánková (2010), the production chain might be considered as a highly complicated system with complex relationships to analyze. Also, similarly, Palát et al (2012) states that numerous factors of the external environment affect agricultural production. On the basis of the econometric analysis of supply, demand as well as price trends, the relations between the individual segments can be examined, quantified and economically described and conclusions can be made regarding the market structure of the given agri-food market.

This paper focuses on wheat that belongs to the most significant agricultural crops grown in the Czech Republic. Studies analyzing this crop vary in terms of the purpose for which the wheat is utilized. Some authors analyze the chain of soft milling wheat, while others focus on its utilization in the feed industry. In the Czech Republic, approximately $40 \%$ of the total production is utilized for foodstuffs utilization. Gallová (2009) analyzed the chain of wheat for feed purposes. The quantification of the price transmission relationship in the paper is based on the assumption of a simultaneous relationship between the price of wheat producers and the prices of processors of feed-stuff mixtures for chicken, pigs and cattle. Blažková, Syrovátka (2012) analyzed price transmission in the chain of soft milling wheat on the basis of monthly data within the period of January 2000 - October 2009. The assessment of price transmission along the wheat commodity chain confirmed the existence of market power especially on the retail stage and low impact of price changes of farm prices on final consumer food prices.

The first studies dealing with econometric analysis of agri-food chains were focused on US markets, and subsequently also expanded to other territories. In recent years, more and more studies also deal with the examination of market relations in central Europe. In terms of studies focusing on plant production, primarily wheat markets, we can mention the following as examples. Palaskas, Crowe (1996) analyzed the seasonality of wheat prices in selected EU states. In their research, Thompson, Herrmann (1999) focused on structural breaks and elasticity of price transmission of wheat prices in Germany. Von Cramon-Taubadel, Loy (1999) addressed symmetry and asymmetry in price transmission on a theoretical level, and application then established asymmetry in price transmissions on markets of the main global exporters. On the basis of comprehensive analysis of selected US markets, Peltzman (2000) showed that price transmission can generally be considered being asymmetrical. Mohsin et al (2006) focused on the analysis of the wheat market in Pakistan on the basis of time series of production, consumption and farm-gate prices, wholesale prices, and the global price of wheat. Brümmer et al (2009), with the utilization of MS-VECM, analyzed price transmissions in the relationship of soft milling wheat and wheat flour in Ukraine. Bakucs et al (2012), with the utilization of MS-VECM, analyzed price transmissions at the level of farm-gate prices of wheat in Hungary and Germany.

The objective of this article is to identify and assess the relationships among the individual segments of the chain of soft milling wheat in the Czech Republic. The analysis itself is divided up into three partial chains, specifically the following:

- soft milling wheat (FP) - smooth wheat flour 00 extra (WP1) - smooth wheat flour (CP1)

- soft milling wheat (FP) - smooth wheat flour (WP2) - white wheat baked goods (CP2)

- soft milling wheat (FP) - wheat bread flour (WP3) - caraway consumer bread (CP3)

The price transmission in agri-food chains might be considered as an important factor in relationships among the farmers and processors as well in relation to the consumers. These days, the farmers and consumers are usually assumed to be price takers while the processors and retail as the institutions which may determine the price level. Thus, this relationship in the selected agri-food chains will be verified in this paper. The analysis itself attempts to answer the following working 
question: "Is it possible to determine the differences in the nature of vertical price transmission among the selected cereals agri-food chains which means that the price transmission in every agri-food chain is unique; or can we consider the nature of selected price transmissions as identical?".

\section{Materials and methods}

The price transmission is analyzed using Vector Error Correction Model (VECM) and co-integration analysis. VECM and co-integration analysis are introduced e.g. in Engle, Granger (1987), Johansen (1991), Chatfield (2004), Kočenda, Černý (2007), Kirchgässner, Wolters (2008) or Juselius (2009). The vertical price transmission in crop agrifood chains was analyzed e.g. in Gallová (2009), Pánková (2010), Reynolds (2010) or Fischer, Hartmann et al. (2010).

The analysis of price transmissions on partial markets within the chain of soft milling wheat is processed in the following steps:

1. Unit Root Tests: ADF (Augmented DickeyFuller Test) and PP (Phillips-Perron Test) tests were employed to detect stationary or non-stationary character of individual time series.

2. Model Derivation: An appropriate form of the time series model was selected according to the results of information criterions, unit root tests and co-integration analysis. In the case of stationary time series VAR (Vector Autoregressive Model) was derived while VECM (Vector Error Correction Model) was selected in the case of non-stationary time series. Co-integration analysis was used to detect and describe the long-run relationship between analyzed time series or agri-food markets, in case of data integration of order 1 or 2, i.e. I(1) or I(2).

VAR model is defined in the following form

$$
\Delta X_{t}=\eta+\sum_{s=1}^{p} C_{s} \Delta X_{t-s}+U_{t},
$$

where $C_{s}=0$ for $s>\mathrm{p}, X_{t}$ is a k x 1 vector of variables supposed to be integrated of order $0,(\mathrm{I}(0)), \mathrm{u}_{1}, \ldots, \mathrm{u}_{\mathrm{t}}$ are nid $(0, \Sigma)$.

VECM model according to Johansen approach was derived as follows:

$$
\Delta X_{t}=\eta+\Pi X_{t-1}+\sum_{s=1}^{p} C_{s} \Delta X_{t-s}+U_{t},
$$

where $C_{s}=0$ for $s>\mathrm{p}, X_{t}$ is a k x 1 vector of variables supposed being integrated of order $1,(I(1)), u_{1}, \ldots, u_{t}$ are nid $(0, \Sigma)$ and is a matrix of the long-term relationship.

3. Residual Analysis: Several additional tests were employed to verify the quality of estimated models. Among others autocorrelation of residuals, normality of their distribution or model volatility were examined.

4. Transmission Elasticity: Coefficients of price transmission elasticity were quantified to define sensitivity of prices at individual agri-food markets.

The analysis of price transmission in agri-food chains of soft milling wheat in the Czech Republic is processed based on the time series containing monthly data for the period of January 1999 - October 2011. In view of the analyzed levels of price transmissions, time series of average monthly farm-gate prices of soft milling wheat in $\mathrm{CZK} / \mathrm{t}$, time series of average wholesale prices of mill and bakery goods in CZK/t (specifically, the time series of smooth wheat flour 00 extra, smooth bakery wheat flour and wheat bread flour are included) were included in the analysis, as well as time series of average consumer prices of mill and bakery goods in CZK/ $\mathrm{kg}$ (specifically the time series of smooth wheat flour, white wheat baked goods and caraway consumer bread).

The analyzed time series contain 154 observations. The data set was provided by the Ministry of Agriculture of the Czech Republic and the Czech Statistical Office. The calculations were done in econometric software RATS and GRETL.

Finally, the results of the price transmission in soft milling wheat agri-food chain detected in analyzed period were verified based on the price transmission analysis in period of January 2012 - December 2015.

\section{Results and discussion}

The examination of the price transmission in the Czech soft milling wheat chain was conducted in three different partial agri-food chains. It can be stated that the time series of farmgate price, wholesale prices and also consumer prices were affected by the financial crisis. The beginning of the global financial crisis was detected in the development of the prices and some consequences of this influence can be still observed. The time series were also examined 
to detect their variability. As the values of coefficient of variation show the biggest variation might be considered in case of farm-gate price of soft milling wheat and consumer price of white wheat baked goods. Variation coefficient reaches the value of 0.25 in these cases. Variability of other examined time series is not as significant as the variability in the time series of FP and CP2. The values of coefficient of variation equals approximately 0.15 . The problem of time series variability is connected to the topic of prices volatility. As Hassouneh et al (2015) states the prices development is commonly analyzed while the examination of prices volatility is not as frequent.

The analysis of price transmission in selected agri-food chains was based on the time series of farm-gate price, wholesale prices and consumer prices. As first, the significant time delay in each time series was selected according to AIC and SBC criterions. Even in some cases the information criterions provided different results as the most significant were selected 6 lags for all time series. Subsequently, ADF and PP tests were employed to detect unit root in analyzed time series. The unit root tests proved that all analyzed time series are non-stationary and integrated of order 1, i.e. I(1). The problems of ADF utilization and quality of its results in case of bread wheat prices are discussed by Bubáková (2013).

Then, co-integration analyses examined the long-run relationship between analyzed prices. Finally, based on previous results the Vector Error Correction Model was considered as a suitable tool to describe the relations in analyzed agri-food chains. The residual analysis provides acceptable results concerning the quality of the quantified relationships. The evaluation of the values of coefficient of elasticity were used to explain the relations in analyzed agri-food chains.

Table 1 compares the main features of estimated Vector Error Correction Models. As it is obvious among others the seasonality in analyzed relations were detected. Derived models proved seasonal character of some periods; nevertheless, the significant seasonal character could not be considered generally. Table 1 also contains the values of Adjusted coefficients of determination. It is obvious that most estimated relations are significant. Low values of the Adjusted coefficient of determination in relations WP1-CP1, WP2-CP2 and WP3-CP3 show possible problems with quantification and explanation of relationships between wholesale price and consumer price in the agri food of soft milling wheat.

Co-integration analysis discovered one co-integrating vector in all analyzed relations. Thus, the long-run relationships between the selected time series were examined based on estimated VECM models. The analysis has proven the long-run relationship in all analyzed partial chains. This result corresponds with the statement of Arnade, Vocke (2016) that wheat prices at different international markets rely on past price transmission and are represented by long-run price trend. The main results about the long-run relations are shown in Table 2 . The table contains the information about the error

\begin{tabular}{|c|c|c|c|c|}
\hline Agri-food market & \multicolumn{2}{|c|}{ FP-WP1 } & \multicolumn{2}{|c|}{ WP1-CP1 } \\
\hline Dependent var. & FP & WP1 & WP1 & $\mathrm{CP} 1$ \\
\hline No. Lags & 6 & 6 & 6 & 6 \\
\hline Seasonality & S8, S9 & S11 & No & $\mathrm{S} 5, \mathrm{~S} 10$ \\
\hline Adjusted R-squared & 0.465423 & 0.524058 & 0.422077 & 0.243574 \\
\hline Agri-food market & \multicolumn{2}{|c|}{ FP-WP2 } & \multicolumn{2}{|c|}{ WP2-CP2 } \\
\hline Dependent var. & FP & WP2 & WP2 & $\mathrm{CP} 2$ \\
\hline No. Lags & 6 & 6 & 6 & 6 \\
\hline Seasonality & S8, S9 & S9 & No & S1, S11 \\
\hline Adjusted R-squared & 0.470658 & 0.506717 & 0.253608 & 0.080799 \\
\hline Agri-food market & \multicolumn{2}{|c|}{ FP-WP3 } & \multicolumn{2}{|c|}{ WP3-CP3 } \\
\hline Dependent var. & FP & WP3 & WP3 & $\mathrm{CP} 3$ \\
\hline No. Lags & 6 & 6 & 6 & 6 \\
\hline Seasonality & S9 & S9, S10 & No & S1 \\
\hline Adjusted R-squared & 0.470768 & 0.514511 & 0.262991 & 0.110120 \\
\hline
\end{tabular}

Source: own calculations

Table 1: VECM - main characteristics. 


\begin{tabular}{lccccc}
\hline EC & Coefficient & Std. Error & t-ratio & P-value & \\
\hline FP-WP1 & -0.12398 & 0.03400 & -3.6463 & 0.00039 & $* * *$ \\
WP1-CP1 & -0.19606 & 0.04788 & -4.0944 & 0.00008 & $* * *$ \\
FP-WP2 & -0.12175 & 0.03048 & -3.9946 & 0.00011 & $* * *$ \\
WP2-CP2 & -0.10664 & 0.02534 & -4.2087 & 0.00005 & $* * *$ \\
FP-WP3 & -0.09184 & 0.02399 & -3.8285 & 0.00020 & $* * *$ \\
WP3-CP3 & -0.12387 & 0.02822 & -4.3895 & 0.00002 & $* * *$ \\
\hline EC & Coefficient & Std. Error & t-ratio & P-value & $*$ *** \\
\hline WP1-FP & 0.05062 & 0.01748 & 2.8952 & 0.00447 & $* .17877$ \\
CP1-WP1 & -0.08488 & 0.06277 & -1.3521 & 0.07928 & $*$ \\
WP2-FP & 0.02712 & 0.01533 & 1.7693 & 0.07928 \\
CP2-WP2 & -0.07007 & 0.04329 & -1.6188 & 0.10801 & \\
WP3-FP & 0.01897 & 0.01349 & 1.4053 & 0.16241 & \\
CP3-WP3 & 0.02879 & 0.02956 & 0.9742 & 0.33184 & \\
Source: own calculations & Table 2: VECM - error correction terms. &
\end{tabular}

correction terms of all estimated VECMs describing long-run relationships between the variables. As the table shows long-run relationship was proven in all analyzed agri-food chains. However, significant mutual relations on significance level $1 \%$ were discovered just in the case of FP-WP1. The relationships in other agri-food chains should be considered as one-way relations. Moreover, agri-food chains can be considered as a demand driven. Thus, it might be concluded that nature of the price transmission in agri-food chain of smooth wheat flour, white wheat baked goods and caraway consumer bread can be considered as identical; even some unique differences were detected.

The examination of the price transmission elasticity (PTE) provided also some important results. On the basis of the values of elasticity of price transmission (see Table 3), it can be stated that variously elastic reactions occur on the individual levels of product chains. However, it cannot be stated overall that elasticity increases or decreases with the higher segments of the chain. The preceding indicates that, on the basis of elasticity of price transmission, the analyzed chains cannot be considered to be reacting and developing identically. The most elastic price transmissions occur in the chain of smooth flour between the wholesale price and the consumer price (the elasticity of price transmission achieves a value of 0.6587 ). The least elastic is the reaction between the farm-gate price and the wholesale price in the chain of consumer bread (the value of elasticity of price transmission is 0.2098) and the wholesale price and the consumer price in the chain of white baked goods (the value of elasticity of price transmission achieves a level of 0.2183 ). These results are partially supported by the result of other authors. The analysis of price transmissions for partial product chains of soft milling wheat in the Czech Republic, specifically flour and baked goods, was addressed, for example, by Blažková, Syrovátka (2012). In their analysis, the elasticity of price transmission was also calculated. Its results, in some cases, correspond to the results set out above, but significant deviations are evident in some cases. Primarily the relationship of the wholesale price - consumer price appears is shown being more elastic in the said study than according to the results set out in Table 3. The deviations can be attributed to the differently selected analyzed time period.

The results deduced based on the price transmission analysis of three partial agri-food chains of soft milling wheat were finally verified based on the data set containing monthly prices of the soft milling wheat in period from 1/2012 until 12/2015. The author assumed that the main conclusions about the price transmission can be generalized; thus, all conclusion are valid in different period. The assumption was partly proved. All analyzed time series were again considered as non-stationary and integrated of order 1 and co-integration analysis has shown long-run relationships among analyzed prices. The long-run relationships can be described mainly as a one-way and demand driven. However, the elasticity of price transmission has shown partly different results. In the period of January 2012

- December 2015 the price transmission seems to be more elastic compared the period January 


\begin{tabular}{lcccccc}
\hline & FP-WP1 & WP1-CP1 & FP-WP2 & WP2-CP2 & FP-WP3 & WP3-CP3 \\
\hline PTE (\%) & 0.39907 & 0.65868 & 0.41299 & 0.21831 & 0.20983 & 0.35663 \\
\hline
\end{tabular}

Source: own calculations

Table 3: Price transmission elasticity.

1999 - October 2011. Thus, one may conclude that the nature of the price transmission in all analyzed agri-food chains is identical; however, partial markets in different periods are also characteristic by some individual specifics.

\section{Conclusion}

The objective of the analysis of this article was to assess the price transmissions in selected partial chains of soft milling wheat in the Czech Republic. The analysis was to answer the question of whether the chains can generally be considered, in view of their relationships based on price transmissions, to be identical or not. The analysis itself showed partial similarities between the analyzed chains, but also indicated certain significant differences.

In terms of the nature and basic characteristics of the individual time series, the analyzed chains, or their partial sections, can be considered to be identical. All of the utilized time series are non-stationary and integrated at a rank of one. This is a typical characteristic of the majority of economic time series, as stated, for example, by Ardeni, Freebairn (2002) or Kennedy (2003). All of the time series further show signs of a seasonal character. Relationships between the individual segments of the analyzed product chains can further be considered to be of a long-term nature. Long-term relationships were also established, for example, in the chain of soft milling wheat in Germany (see Bavorová, Hockman (2010)).

Besides the said basic similarities and differences within the analyzed chains, the sphere of results and their significance can be extended to other related agri-food chains. In some cases, the ascertained conclusions can even be generalized for a broader sphere of agri-food markets.

As is known, wheat as an agricultural crop can be utilized not only for foodstuffs purposes, but also as a feed crop for farm animals. For example, Pánková (2010) analyzed price transmission in the agri-food chain of wheat for feed purposes in the Czech Republic. The analysis shows that wheat for feeding (poultry, pork) might be considered a demand-driven system. On the basis of the said analysis itself, it can thus be stated that the wheat market in all of its partial chains can be considered to be demand-oriented.

In the analysis of price transmission, attention was also paid to the volatility of individual time series. Differences were ascertained in its form prior to and after the accession of the Czech Republic to the EU. It can be stated that prior to the accession of the Czech Republic to the EU, the volatility of time series was lower than after its accession. Onour, Sergi (2011) analyzed prices of food commodities on the world market. The analysis shows that their volatility is characterized by the intermediate and short memory behavior and is mean reverting.

The actual functioning of the product chains is, besides the analyzed relationships between the farmgate price, the wholesale price, and the consumer price and the segments of the chains corresponding to them, more and more strongly affected by the operation of retail chains, retail networks in general, which thanks to their strength and position "deform" economic principles and rules for their own benefit. As stated by Lu et al (2010), in managing a long-term trading relationship within the agri-food chain, it is important to appreciate that exchange partners will only enter into a relationship when they expect to receive returns that are greater than those they can obtain elsewhere. However, in the case of market deformities in the form of asymmetrical information or prices set in imperfect competition, the position of all of the market participants is not equal and thus access to the market relationship and a real opportunity for a "fair" transaction can be distorted. As stated by Grazia et al (2010), the quality and form of relationships in the chain and communication between the individual segments of the chain are closely related to its competitiveness.

In conclusion, it can be stated, as explained by $\mathrm{Lu}$ et al (2010), that building and maintaining good business relationships requires care and effort, just like growing agricultural products. However, the emphasis of the elements of managing business relationships differs at various chain stages and with different partners. Thus, it is widely agreed that building and maintaining good, sustainable 
business relationships can lower transaction costs and reset in competitive advantages, which will benefit both sellers and buyers in agri-food chains. The major ingredients for planting business relationships are selecting the right partner, aligning business goals and procedures, and allocating appropriate resources.

\section{Acknowledgements}

The results set out in this article are the result of research as part of the grant project "P402/11/ P591 Modeling of price transmission and its asymmetry in agri-food chain - theoreticalempirical implications" supported by the Grant Agency of the Czech Republic.

Corresponding author:

Ing. Lenka Rumánková, Ph.D.

Department of Economics, Faculty of Economics and Management,

Czech University of Life Sciences Prague, Kamýcká 129, 16521 Prague 6, Czech Republic

Phone: +420 22438 2077,E-mail: rumankova@pef.czu.cz

\section{References}

[1] Ardeni, P. G. and Freebairn, J. (2002) „The Macroeconomics of Agriculture", Handbook of Agricultural Economics, Vol. 2, Agriculture and its External Linkages. North-Holland, Netherlands. ISBN 0-444-51080-XX.

[2] Arnade, C. and Vocke, G. (2016) ,Seasonal Variation in the Price Discovery Process of International Wheat", Agribusiness, Vol. 32, No. 1, Winter 2016. ISSN 0742-4477.

[3] Bakucs, L. Z., Brümmer, B., von Cramon-Taubadel, S. and Fertö, I. (2012),,Wheat market integration between Hungary and Germany“, Applied Economics Letters, Vol. 19, No. 8. ISSN 1350-4851.

[4] Bavorová, M. and Hockmann, H. (2010) „Reviewing Relationship Sustainability in the Case of German Wheat-to-Bread Chain“, in Agri-food chain relationships. CABI, UK. ISBN 978-1-84693-642-6.

[5] Blažková, I. and Syrovátka, P. (2012), Price formation and transmission along the food commodity chain“, Acta Universitatis Agriculturae et Silviculturae Mendeleiane Brunensis, Vol. LX, No. 4/2012. ISSN 1211-8516.

[6] Bubáková, P. (2013) "Effect of Economic Changes on Time Series Modelling and Testing of Bread Wheat Prices", Scientia Agriculturae Bohemica, Vol. 44, No. 3. ISSN 1211-3174.

[7] Brümmer, B., von Cramon-Taubadel, S. and Zorya, S. (2009) „The impact of market and policy instability on price transmission between wheat and flour in Ukraine“, European Review of Agricultural Economics, Vol. 36, No. 2. ISSN 0165-1587. DOI 10.1093/erae/jbp021.

[8] Czech Statistical Office (2016). [Online]. Available: http://www.czso.cz [Accessible: 23. Aug 2016].

[9] Engle, R. and Granger, C. W. J. (1987) „Co-integration and Error Correction: Representation, Estimation and Testing“, Econometrica, Vol. 55, No. 2. ISSN 1468-0262. DOI 10.2307/1913236.

[10] Fischer, Ch. and Hartmann, M. (2010) "Agri-food Relationships", CABI, UK. ISBN 978-1-84593-642-6.

[11] Gallová, L. (2009) „The analysis of price transmission in the chosen production chain“, Scientia Agriculturae Bohemica, Vol. 40, No. 4. ISSN 1211-3174.

[12] Grazia, A., de Magistris, T. and Albisu, L. M. (2010) „Inter-organizational Relationships as Determinants for Competiteveness in the Agri-food Sector: the Spanish Wheat-to-Bread Chain", in Agri-food chain relationships. CABI, UK. ISBN 978-1-84693-642-6.

[13] Hassouneh, I., Serra, T., Bojnec, Š. and Gil, J. M. (2015) "Modeling price transmission and volatility spillover in the Slovenian wheat market", $25^{\text {th }}$ ICAE Conference, Milan, Italy, [Online]. Available: http://ageconsearch.umn.edu/bitstream/211711/2/Hassouneh-Modeling\%20price\%20 transmission\%20and\%20volatility\%20spillover-249.pdf [Accessed: 21. March 2016]. 
[14] Chatfield, Ch. (2004) „The analysis of time series - an introduction“, Chapman \& Hall/CRC, USA. ISBN 1-58488-317-0.

[15] Johansen, S. (1991), Estmation and Hypothesis Testing of Cointegration Vectors in Gaussian Vector Autoregressive Models“, Econometrica, Vol. 59, No. 6. ISSN 1468-0262. DOI 10.2307/2938278.

[16] Juselius, K. (2009) „The cointegrated VAR model - methodology and applications“, Oxford University Press, UK. ISBN 978-0-19-928567-9.

[17] Kenneddy, P. (2003) „A Guide to Econometrics“, MIT Press, USA. ISBN 0-262-11280-9.

[18] Kim, R. B. (2012) „Determinants of brand equity for credence goods: Consumers’ preference for country origin, perceived value and food safety“, Agric. Econ. - Czech, Vol. 58, No. 7. ISSN 0139-570X.

[19] Kirchgässner, G. and Wolters, J. (2008) „Introduction to modern time series analysis“, Springer, Berlin. ISBN 978-3-540-68735-1.

[20] Kita, J., Máziková, K., Grossmanová, M. and Kita, P. (2012) :Trade practices of retail chains as far as the transaction cost analysis in the relationships manufacturer - retailer are concerned in the milk industry“, Agric. Econ. - Czech, Vol. 58, No. 6. ISSN 0139-570X. DOI 10.3846/btp.2012.07.

[21] Kočenda, E. and Černý, A. (2007) „Elements of Time Series Econometrics: An Applied Approach“, Karolinum Press, Prague. ISBN 978-80-246-1370-3.

[22] Lu, H., Batt, P. J. and Fischer, Ch. (2010) „Best Practice in Relationship Management: Recommendations for Farmers, Processors and Retailers“, in: Agri-food chain relationships. CABI, UK. ISBN 978-1-84693-642-6.

[23] Luňáček, J. and Feldbabel, V. (2011) „Elasticity of demand of the Czech consumer“, Acta Universitatis Agriculturae et Silviculturae Mendeleiane Brunensis, Vol. LIX, No. 7. ISSN 1211-8516. DOI 10.11118/actaun201159070225.

[24] Ministry of Agriculture of the Czech Republic (2016). [Online]. Available: http://www.mze.cz [Accessible: 15.Nov. 2016].

[25] Mohsin, A. Q., Mukhtar, T. and Jabine, S. (2006), ,The implications of WTO agreement on production and consumption of wheat in Pakistan: A time series analysis“, Journal of Applied Science, Vol. 6, No. 1, 2006. ISSN 1812-5654.

[26] Onour, I. A. and Sergi, B. S. (2011) „Modeling and forecasting volatility in the global food commodity prices“, Agric. Econ. - Czech, Vol. 57, No. 3. ISSN 0139-570X.

[27] Palaskas, T. B. and Crowe, T. J. (1996) „Testing for price transmission with seasonally integrated producer and consumer price series from agriculture“, European Review of Agricultural Economics, Vol. 23, No. 4, 1996. ISSN 0165-1587.

[28] Palát, M., Dvořáková, Š. and Kupková, N. (2012) „Consumption of beef in the Czech Republic“, Agric. Econ. - Czech, Vol. 58, No. 7. ISSN 0139-570X.

[29] Pánková, L. (2010) „Specifics in the chosen production chain?“, Agris on-line Papers in Economics and Informatics, Vol. II, No. 4. ISSN $1804-1930$.

[30] Peltzman, S. (2000) „Prices Raise Faster Than They Fall“, Journal of Political Economy, Vol. 108, No. 3. ISSN 1537-534X.

[31] Putičová, M. and Mezera, J. (2011) „Competiveness of the Czech food industry“, Agric. Econ. Czech, Vol. 57, No. 9. ISSN 0139-570X.

[32] Reynolds, N. (2010) „Factors influencing business relationships in agri-food chains - an analysis of selected German chains in European comparison“, Josef Eul Verlag, Köln. ISBN 978-3-8441-0004-4. 
[33] Syrovátka, P. (2006) „Income elasticity of demand within individual consumer groups and the level of income elasticity of the entire market demand", Agric. Econ. - Czech, Vol. 52, No. 9. ISSN 0139-570X.

[34] Šrédl, K. and Soukup, A. (2011) „Consumer's behaviour on food markets“, Agric. Econ. - Czech, Vol. 57, No. 3. ISSN 0139-570X.

[35] Thompson, S. and Herrmann, R. (1999) „Wheat price transmission and CAP policy reform“, American Journal of Agricultural Economics, Vol. 81, No. 5. ISSN 0002-9092.

[36] von Cramon-Taubadel, S. and Loy, J. P. (1999), ,The identification of asymmetric price transmission processes with integrated time series“, Jahrbucher fur Nationalokonomie und Statistik, Vol. 218, No. 1-2. ISSN 0021-4027. 